\title{
Keefektifan Model Project Based Learning Berbantu Multimedia Power Point Terhadap Hasil Belajar IPA
}

\author{
Rofiqoh Nadila Cahyaningsih ${ }^{*}$, Joko Siswanto², Sukamto ${ }^{3}$
}

123 Universitas PGRI Semarang

\begin{abstract}
Abstrak
Penelitian ini bertujuan untuk mengidentifikasi keefektifan model Project Based Learning terhadap hasil belajar IPA kelas V SD Negeri 1 Pasar Banggi Rembang. Penelitian ini termasuk penelitian eksperimen jenis kuantitatif dengan desain penelitian Pre-Experimental Desaigns jenis one-group pretest posttest design. Populasi yang digunakan dalam penelitian ini adalah seluruh peserta didik kelas V SD Negeri 1 Pasar Banggi Rembang yang berjumlah 20 siswa tahun ajaran 2019/2020. Data dalam penelitian diperoleh melalui (1) tes (2) wawancara dan (3) dokumentasi. Untuk analisis data dalam penelitian ini menggunakan uji normalitas awal, uji normalitas akhir, uji ketuntasan belajar dan uji-t (uji hipotesis). Uji normalitas dilakukan guna mengetahui data kelas tersebut berdistribusi normal atau tidak. Uji ketuntasan belajar dilaksanakan guna mengetahui tuntas atau tidaknya hasil belajar siswa dengan tolak ukur KKM (Kriteria Ketuntasan Minimum). Uji hipotesis menggunakan uji t-test. Hasil analisis pretest dan posttest siswa sebelum dan sesudah diberikannya perlakuan menggunakan model pembelajaran Project Based Learning mengalami peningkatan. Hal ini dapat dilihat dari rata-rata hasil posttest lebih tinggi dari hasil pretest selain itu diperkuat dengan adanya perhitungan uji $t$ diperoleh thitung untuk hasil belajar sebesar 15,600dan tabel sebesar 2,023 karena thitung $>t_{\text {tabel }}$ maka hal ini menunjukkan bahwa uji $t$ hasil belajar signifikan. Maka kesimpulannya adalah model Project Based Learning efektif terhadap hasil belajar siswa.
\end{abstract}

\begin{abstract}
This study aims to identify the effectiveness of the Project Based Learning model for the learning outcomes of Natural Sciences V grade SD Negeri 1 Pasar Banggi Rembang. This research is a quantitative type of experimental research with a Pre-Experimental Desaigns research design type one-group pretest posttest design. The population used in this study were all fifth grade students of SD Negeri 1 Pasar Banggi Rembang, totaling 20 students in the 2019/2020 school year. Data in this study were obtained through (1) tests (2) interviews and (3) documentation. For data analysis in this study using the initial normality test, the final normality test, the learning completeness test and the t-test (hypothesis test). Normality test is performed to determine whether the class data has normal distribution or not. The mastery learning test is carried out in order to find out whether or not the student learning outcomes are complete with the KKM benchmark (Minimum completeness criteria). Hypothesis testing uses t-test. The results of the pretest and posttest analysis of students before and after the treatment was given using the Project Based Learning learning model increased. This can be seen from the average posttest results which are higher than the pretest results other than that it is reinforced by the $t$-test calculation obtained $t_{\text {count }}$ for learning outcomes of 15,600 and $t_{\text {table }}$ of 2,023 because $t_{\text {count }}>t_{\text {table }}$ then this shows that the $t$ test of learning outcomes is significant. So the conclusion is that the Project Based Learning model is effective against student learning outcomes.
\end{abstract}

\footnotetext{
* Corresponding author.

E-mail Addresses: - Rofiqohnadila@gmail.com@gmail.com (Rofiqoh Nadila Cahyaningsih)
} 


\section{PENDAHULUAN}

Muatan pembelajaran dalam Kurikulum 2013 ada 8, salah satunya adalah muatan pembelajaran Ilmu Pengetahuan Alam. Hal tersebut tercantum dalam Permendikbud Nomor 21 Tahun 2016 Tentang Standar isi untuk Satuan Pendidikan Dasar dan Menengah pada Kurikulum 2013 yang menjelaskan bahwa, terdapat muatan Ilmu Pengetahuan Alam pada jenjang SD/MI/SDLB/Paket A dan SMP/MTS/SMPLB/Paket B. Memperhatikan isi yang tercantum dalam dalam Permendikbud Nomor 21 Tahun 2016 Tentang Standar isi, telah jelas bahwa muatan Ilmu Pengetahuaan Alam telah diterapkan sebagai muatan pembelajaran di Sekolah Dasar, lengkap dengan ruang lingkup materi yang digunakan sebagai pembelajaran. Materi pembelajaran yang akan diajarkan haruslah mampu mencapai tujuan pembelajaran atau capaian pembelajaran.

Berdasarkan Permendikbud Nomor 22 Tahun 2016, capaian pembelajaran dapat dikelompokkan dalam tiga ranah yakni ranah kognitif, afektif dan psikomotor. Proses pembelajaran sepenuhnya diarahkan pada pengembangan ketiga ranah tersebut secara utuh/holistik, artinya pengembangan ranah yang satu tidak bisa dipisahkan dengan ranah lainnya. Dengan demikian proses pembelajaran secara utuh melahirkan kualitas pribadi dalam aspek sikap, pengetahuan, dan keterampilan.

Capaian pembelajaran yaitu ranah kognitif, ranah afektif dan psikomotor maka diharapkan pembelajaran yang telah dilakukan akan berjalan dengan baik, namun dalam kenyataannya masih banyak ditemukan permasalahan dalam pembelajaran IPA. Hal ini terbukti dari penelitian PISA (the Programme for International Student Assesment) yang berisi tentang daya saing dan inovasi siswa negara-negara Organization forEconomic Co-operation and Development (OCED). Sasaran survei PISA 2015 adalah siswa usia 15 tahun. Berdasarkan hasil PISA 2015, Indonesia berada di peringkat 62 dari 70 negara yang berpastisipasi. Skor yang dicapai oleh siswa Indonesia kurang lebih adalah 403.

Mata pelajaran IPA masih perlu diperhatikan, dengan realita permasalahan yang ada di lapangan masih terjadi kesenjangan pada pembelajaran IPA di SD Negeri 1 Pasar Banggi Rembang. Berdasarkan studi pendahuluan untuk mengetahui permasalahan yang ada di kelas bersama dengan guru kelas V SD Negeri 1 Pasar Banggi Rembang dan diperoleh informasi bahwa dalam kegiatan belajar mengajar guru belum menerapkan model pembelajaran yang inovatif. Pembelajaran IPA masih berpusat pada guru dan siswa kurang dilibatkan dalam pembelajaran. Sedangkan pada umumnya pembelajaran IPA haruslah mengajak siswa secara aktif dalam menggali sebuah pengetahuan. Selain itu, media belajar yang digunakan guru kurang bervariasi. Guru hanya menggunakan buku dan gambar sebagai media pembelajaran, sehingga pembelajaran menjadi kurang menarik perhatian siswa, terlebih guru sangat jarang menggunakan media pembelajaran yang berbasis teknologi seperti LCD, hal ini terjadi karena guru terkendala kesulitan dalam penggunaan komputer, yang menjadikan media pembelajaran yang kurang bervariasi dan menurunnnya antusias siswa dalam pembelajaran. Serta siswa kurang dilibatkan dalam berfikir secara kritis, yang mengakibatkan hasil belajar menjadi rendah dan jauh dari tujuan yang ingin dicapai.

Berdasarkan informasi yang diperoleh tentang proses belajar mengajar yang digunakan pada saat pembelajaran yang masih berpusat pada guru sehingga kurangnya keterlibatan siswa pada saat pembelajaran yang mengakibatkan rendahnya hasil belajar siswa, terbukti dari data observasi nilai ratarata pencapaian hasil evaluasi belajar siswa kelas V SD Negeri 1 Pasar Banggi Rembang pada pembelajaran IPA dalam materi Hubungan Antarmakhluk hidup dan lingkungannya. Kriteria Ketuntasan Minimum (KKM) padamateri Hubungan Antarmakhluk hidup dan lingkungannya yang ditetapkan sekolah adalah 65. Dari jumlah siswa kelas V ada 26 siswa, diantaranya siswa laki-laki ada 14 siswa dan siswa perempuan ada 12 siswa. Data hasil belajar yang diperoleh menunjukkan bahwa dari 26 siswa, ada 11 siswa yang mendapatkan nilai diatas KKM sedangkan 15 siswa mendapat nilai dibawah KKM. Oleh karena itu, perlu menciptakan pembelajaran yang inovatif, bermakna, kontruktivis, dan memotivasi siswa untuk berpartisipasi aktif sehingga menumbuhkan hasil belajar terhadap pembelajaran IPA.

Hasil temuan yang lain, dimana guru belum mampu memberikan pemahaman konsep, terlihat dari penggunaan model pembelajaran yang konvensional dan pemberian tugas individu sehingga siswa menjadi bosan, tidak ada kerjasama dengan siswa lain dan rendahnya pemahaman siswa terhadap materi yang diajarkan. Kurangnya penggunaan media dan pemberian materi yang hanya terfokus pada buku teks membuat siswa belum memahami materi pembelajaran dan membuat siswa tidak memperhatikan guru saat memberikan penjelasan. Mereka sering gaduh sendiri di dalam kelas, bicara dengan temannya yang tidak ada hubungannya dengan materi pelajaran yang berakibat siswa tidak dapat mengerjakan soal. Hal ini mempengaruhi hasil belajar siswa. Jika dengan cara seperti itu tetap dilanjutkan dipastika banyak siswa yang pasif dan diam, tidak mau bertanya jika ada hal yang belum mereka pahami.

Pembelajaran IPA yang dilakukan oleh guru masih terapat permasalahan dimana pembelajaran IPA guru masih belum mampu menerapkan pemahaman konsep terlihat dari model yang digunakan kurang 
inovatif yang mana model yang digunakan masih konvensional guru sebagai pusat dan siswa kurang dilibatkan dalam proses pembelajaran sehingga banyak siswa yang pasif dalam pembelajaran. Serta seringnya pemberian tugas individu sehingga siswa menjadi bosan, tidak ada kerjasama dengan siswa lain dan rendahnya pemahaman siswa terhadap materi yang diajarkan, yang mengakibatkan hasil belajar menjadi rendah dan jauh dari tujuan yang ingin dicapai. Maka perubahan diperlukan sekali untuk mengubah cara belajar siswa di SD Negeri 1 Pasar Banggi Rembang tersebut, dengan cara menjadikan anak aktif dalam pembelajaran. Pembelajaran yang efektif, efisien serta menyenangkan diharapkan dapat memotivasi siswa dalam belajar sehingga aktivitas siswa meningkat. Keterbatasan guru dalam menangani siswa satu persatu juga menjadi salah satu kendala. Berdasarkan hal-hal tersebut, untuk mengoptimalkan proses belajar mengajar diperlukan langkah tepat yang dapat diterapkan secara tepat guna mengatasi permasalahan tersebut. Agar nantinya diharapkan hasil belajar siswa mendapatkan nilai yang melebihi KKM.

Peneliti menerapkan model yang digunakan yaitu model pembelajaran Project Based Learning. Model PjBL dapat mengembangkan kemampuan berpikir kritis siswa, meningkatkan kemampuan pemecahan masalah yang kompleks, dengan melibatkan siswa untuk melakukan pengamatan, diskusi, dan pembuatan karya yang dapat memperjelas materi. Seperti yang dinyatakan oleh Sanibahwa proses pembelajaran melalui Project Based Learning memungkinkan aktivitas jangka panjang yang melibatkan siswa dalam merancang, membuat dan menampilkan produk untuk mengatasi permasalahan dunia nyata. Dengan menggunakan sistem pengajaran yang aktiv, maka akan memacu kreativitas siswa dengan belajar membuat sesuatu (Learning by making). Kemudian Model pembelajaran berbasis proyek (Project Based Learning) menurut The George Lucas Education Foundation (2005) mengungkapkan bahwa dalam pembelajaran berbasis proyek, siswa diberi tugas dengan mengembangkan tema/topik dalam pembelajaran dengan melakukan kegiatan proyek yang realistik. Disamping itu penerapan pembelajaran berbasis proyek ini mendorong tumbuhnya kreativitas, kemandirian, tanggung jawab, kepercayaan diri, serta berpikir kritis, dan analisis pada siswa.

Fokus pembelajaran Project Based Learning terletak pada prinsip dan konsep inti dari suatu disiplin ilmu, melibatkan siswa dalam investigasi pemecahan masalah dan kegiatan tugas-tugas bermakna yang lain, memberi kesempatan siswa bekerja secara otonom dalam mengontruksi pengetahuan mereka sendiri, dan mencapai puncaknya untuk menghasilkan produk nyata (Wena, 2010). Jadi dengan menerapkan PjBL dalam pembelajaran IPA, siswa diajak untuk belajar bersama dan berpikir hingga menghasilkan suatu produk nyata yang berkaitan dengan materi.

Berdasarkan uraian tersebut, peneliti tertarik untuk meneliti keefektifan model PjBL (Project Based Learning ) berbantuan Multimedia Power Point. Penelitian ini didukung oleh penelitian sebelumnya yaitu penelitian yang dilakukan oleh Santi Kusuma Fajarwatidengan judul "Pengaruh Project Based Learning Berbantu Multimedia Terhadap Keterampilan Memecahkan Masalah Dan Hasil Belajar Psikomotor Siswa Kelas IX SMA". Hasil penelitian menunjukkan bahwa terdapat pengaruh model pembelajaran Project Based Learning Berbantu Multimedia terhadap ketrampilan memecahkan masalah siswa dan hasil belajar psikomotor siswa.

Berdasarkan permasalahan diatas maka perlu dilakukan perbaikan pembelajaran agar siswa mampu berpikir secara kritis dan aktif sehingga hasil belajar siswa meningkat. Salah satunya dengan menggunakan model Project Based Learning pada pembelajaran IPA Kelas V.

Tujuan dari penelitian ini adalah untuk mengetahui keefektifan model Project Based Learning terhadap hasil belajar IPA siswa kelas V.

\section{METODE PENELITIAN}

Penelitian ini menggunakan metode kuantitatif yaitu dengan cara memberikan perlakuan kegiatan dalam pembelajaran di kelas. Desain penelitian yang digunakan dalam penelitian ini adalah PreExperimental Desaigns dengan bentuk desain one-group pretest posttest design.

Penelitian dilaksanakan di SD Negeri 1 Pasar Banggi Rembang pada tanggal 10-12 Desember 2019 pada tahun ajaran 2019/2020 semester gasal pada siswa kelas V.

Populasi yang digunakan pada penelitian ini adalah seluruh peserta didik kelas V SD Negeri 1 Pasar Banggi Rembang berjumlah 20 siswa tahun ajaran 2019/2020. Dalam desain yang digunakan ini subjek diberikan perlakuan dengan dua kali pengukuran, penilaian pertama dilakukan sebelum diberikannya perlakuan dengan model Project Based Learning (pretest) dan pengukuran ke dua dilakukan setelah diberikannya perlakuan dengan model Project Based Learning (posttest). Dengan demikian hasil perlakuan dapat terlihat lebih akurat, karena dapat membandingkan dengan keadaan sebelum diberikan perlakuan. Desain ini dapat digambarkan sebagai berikut: 


\section{$\mathrm{O}_{1} \times \mathrm{O}_{2}$}

Gambar 1. Rancangan Desain Penelitian

\section{Keterangan:}

$\mathrm{O}_{1}=$ nilai pretest (sebelum diberi perlakuan menggunakan model Project Based Learning).

$\mathrm{O}_{2}=$ nilai postest(setelah diberi perlakuan menggunakan model Project Based Learning).

$\mathrm{X}=$ perlakuan (pembelajaran menggunakan model Project Based Learning).

Teknik pengumpulan data dalam penelitian ini adalah tes, wawancara, observasi dan dokumentasi. Wawancara bertujuan untuk mendapatkan informasi tentang kondisi awal siswa serta materi yang akan diajarkan.

Dokumentasi dalam penelitian ini digunakan untuk dokumen pelaksanaan kegiatan pembelajaran selama penelitian. Untuk observasi dilakukan guna mendapatkan data sekolah mengenai nama siswa, jumlah siswa, dan data-data yang diperlukan dalam penelitian.

Data hasil belajar siswa yang diambil dari hasil pretest dan posttest. Pretest untuk memperoleh data hasil belajar siswa sebelum perlakuan pembelajaran dengan menggunakan model Project based Learning dan posttest untuk memperoleh data hasil belajar siswa setelah diberikan perlakuan pembelajaran menggunakan model Project Based Learning.

Peserta didik dikatakan berhasil mencapai hasil belajar jika nilai diatas KKM (Kriteria Ketuntasan Minimum), yaitu $>65$. Pengembangan instrumen tes terdiri atas beberapa tahapan, yaitu: (1) mengkaji silabus mata pelajaran IPA kelas V SD; (2) menyusun kisi-kisi tes didasarkan pada teori yang dikembangkan oleh bloom; (3) menulis butir soal; (4) menelaah nutir soal; (5) melakukan uji coba; dan (6) menganalisis butir soal.

Setelah proses validasi berdasarkan pendapat ahli dilakukan, instrumen diuji cobakan pada siswa kelas VI SD yang memiliki karakteristik yang hampir sama dengan siswa yang menjadi subjek penelitian ini.

Teknis analisis data peneliti menggunakan uji normalitas, uji ketuntasan belajar, uji homogenitas (uji-t). Uji normalitas dilakukan guna mengetahui data yang berdistribusi normal. Uji ketuntasan belajar dilaksanakan guna mengetahui tuntas atau tidaknya hasil belajar siswa dengan tolak ukur KKM (Kriteria Ketuntasan Minimum).

\section{ANALISIS DAN PEMBAHASAN}

Penelitian Hasil penelitian ini subjek dikenakan perlakuan dua kali pengukuran, yang pertama sebelum kegiatan dengan menggunakan model pembelajaran Project Based Learning, siswa diberikan soal pretest, kemudian yang kedua setelah kegiatan dengan menggunakan model pembelajaran Project Based Learning diberikan soal posttest. Peneliti mengambil satu kelas sebagai sampel penelitian. Pengambilan sampel ini didasarkan pada kelas yang berdistribusi normal.

Data hasil penelitian uji normalitas awal menggunakan uji liliefors hasil pretest yang hasilnya didapatkan bahwa $\mathrm{L}_{0}$ hasil belajar $(0,1164)<\mathrm{L}_{\text {tabel }}(0,190)$ maka $\mathrm{H}_{0}$ diterima, sehingga sampel berasal dari populasi berdistribusi normal. Sedangkan dari data uji normalitas menggunakan uji liliefors untuk nilai hasil posstest memenuhi kriteria pengujian yaitu $\mathrm{L}_{0}(0,1422)<\mathrm{L}_{\text {tabel }}(0,190)$, hal ini menunjukkan bahwa sampel hasil posttest berdistribusi normal. Untuk mengetahui apakah model pembelajaran Project Based Learning efektif terhadap hasil belajar IPA kelas V SD Negeri 1 Pasar Banggi Rembang ini dilakukan analisis tahap akhir yaitu uji t. Hasil analisis data akhir untuk pengujian hipotesis pada hasil belajar pretest dan posttest didapatkan $t_{\text {hitung }}(15,601)>t_{\text {tabel }}(2,023)$ untuk nilai hasil belajar, dimana menunjukkan bahwa $t_{\text {hitung }}$ berada pada daerah penerimaan $\mathrm{H}_{\mathrm{a}}$. Hal ini menunjukkan bahwa apakah model pembelajaran Project Based Learning efektif terhadap hasil belajar matematika kelas V SD Negeri 1 Pasar Banggi Rembang.

Tabel 1. Data Presentase Ketuntasan Hasil Belajar Peserta Didik

\begin{tabular}{|c|c|c|}
\hline \multirow[t]{2}{*}{ Keterangan } & \multicolumn{2}{|c|}{ Hasil Belajar } \\
\hline & Pretest & Posttest \\
\hline Jumlah & 20 & \\
\hline Rata-rata & 47,5 & 83,5 \\
\hline
\end{tabular}




\begin{tabular}{lcc}
\hline Siswa Tuntas & 5 & 17 \\
Siswa Tidak Tuntas & 15 & 3 \\
Presentase Kenaikan & $60 \%$ & \\
\hline
\end{tabular}

Dari tabel 1 didapatkan rata-rata nilai tes sebelum diberi perlakuan dengan model pembelajaran Project Based Learning sebesar 47,5 dengan jumlah siswa yang dinyatakan tuntas sebanyak 5 dan 15 siswa dinyatakan tidak tuntas. Setelah diberikan pembelajaran dengan model pembelajaran Project Based Learning nilai rata-rata posttest siswa adalah 83,5 dengan 17 siswa tuntas, sedangkan siswa tidak tuntas hanya 3 siswa. Presentase kenaikan sebesar 60\%. Berdasarkan perhitungan diatas dapat diketahui bahwa kemampuan awal diperoleh rata-rata yang relatif rendah. Sedangkan setelah mendapatkan perlakuan dengan model Project Based Learning terdapat peningkatan yang signifikan terhadap hasil belajar siswa.

Selanjutnya ada aspek afektif, peneliti menggunakan 2 kali pengukuran sikap yang diambil data dan dianalisis untuk dibuktikan bahwa model Project Based Learning lebih efektif terhadap hasil belajar IPA kelas V SD N 1 Pasar Banggi Rembang. Penilaian sikap ini dilaksanakan dengan pengamatan sepanjang kegiatan pembelajaran dengan aspek yang dinilai antara lain percaya diri, peduli, tanggung jawab, disiplin. Berikut adalah data hasil penilaian sikap siswa pada saat pembelajaran:

Tabel 2. Data Penilaian Sikap Peserta Didik

\begin{tabular}{lcc}
\hline & Keterangan & \multicolumn{2}{c}{ Penilaian Sikap } \\
\cline { 2 - 3 } & Pembelajaran 1 & Pembelajaran 2 \\
\hline Jumlah & 20 & 75 \\
Nilai Tertinggi & 62,5 & 100 \\
Nilai Terendah & 87,5 & 81,88 \\
\hline Rata-rata & 70,63 & \\
\hline
\end{tabular}

Berdasarkan dari Tabel 2 dapat dilihat perhitungan bahwa rata-rata nilai sikap siswa pada pertemuan 1 sebesar 70,63, dan rata-rata pada pertemuan 2 sebesar 81,88, maka dapat dilihat bahwa rata-rata nilai sikap siswa terjadi peningkatan dari pertemuan 1 hingga pertemuan 2 .

Pada aspek psikomotor, peneliti menggunakan 2 proyek yang diambil dari data dan dianalisis untuk dibuktikan bahwa model pembelajaran Project Based Learning lebih efektif terhadap hasil belajar IPA kelas V SD Negeri 1 Pasar Banggi Rembang, satu hari peneliti menggunakan 1 tugas dalam bentuk proyek pada pembelajaran yang berlangsung di kelas. Pada hari pertama siswa diminta untuk membuat sebuah peta pikiran mengenai konsep rantai makanan sesuai dengan pembagian ekosistem. Proses pembuatan peta pikiran ini diawali dengan pembagian ekosistem yang didapat pada setiap kelompok, kemudian diskusi mengenai konsep yang akan dibuat. Pada hari kedua, siswa membuat hasil nyata dari konsep yang telah dibuat dengan bentuk diorama.

Pembuatan tugas proyek ini dinilai dengan beberapa aspek diantaranya yaitu Desain, keterampiran berbicara, kerapian, ketepatan. Berikut ini adalah data hasil penelitian tugas proyek siswa saat pembelajaran:

Tabel 3. Daftar Nilai Keterampilan proyek siswa

\begin{tabular}{lcc}
\hline \multicolumn{1}{c}{ Keterangan } & \multicolumn{2}{c}{ Penilaian Proyek Siswa } \\
\cline { 2 - 3 } & Proyek 1 & Proyek 2 \\
\hline Jumlah & 20 & 75 \\
Nilai Tertinggi & 62,5 & 100 \\
Nilai Terendah & 87,5 & 78,8 \\
\hline Rata-rata & 69,38 & \\
\hline
\end{tabular}

Kelebihan penggunaan model pembelajaran Project Based Learning dalam pembelajaran dikelas yaitu mampu meningkatkan pemahaman dan kreativitas siswa melalui proyek yang telah dibuat. Serangkaian tugas proyek yang telah dibuat secara individu maupun kelompok ini yang mampu meningkatkan pemahaman siswa terhadap materi yang telah diajarkan serta kreativitas yang dibangun melalui pembuatan proyek. Selain itu model pembelajaran ini mampu mengubah siswa dari pasif menjadi aktif saat pembelajaran, kemudian menjadikan siswa yang bertanggung jawab saat proses pembelajaran berlangsung, diskusi yang kurang terarah menjadikan suasana di dalam kelas menjadi gaduh sehingga mengurangi efisiensi waktu. 
Terlepas dari kekurangan yang ada pada penelitian ini, hasil belajar IPA siswa mengalami peningkatan sebesar $60 \%$. Sikap dan aktifitas siswa mengalami peningkatan sehingga berdampak pada hasil belajar siswa yang memuaskan. Setelah dilakukan perhitungan uji hipotesis pada analisis data dan analisis penilaian sikap dan keterampilan proyek siswa yang telah diselesaikan diperoleh kesimpulan sebagai hasil penelitian menyatakan bahwa model pembelajaran Project Based Learning efektif terhadap Hasil Belajar IPA kelas V SD Negeri 1 Pasar Banggi Rembang. Penerapan model pembelajaran Project Based Learning telah terbukti meningkatkan hasil belajar siswa.

\section{KESIMPULAN}

Berdasarkan hasil penelitian yang telah dilakukan dapat disimpulkan bahwa model pembelajaran Project Based Learning efektif terhadap hasil belajar IPA kelas V SD Negeri 1 Pasar Banggi Rembang. Hal ini berdasarkan hasil penelitian menggunakan uji $t$ diperoleh $t_{\text {hitung }}>t_{\text {tabel }}$ yaitu 15,601 > 2,023, maka $\mathrm{H}_{0}$ ditolak dan $\mathrm{H}_{\mathrm{a}}$ diterima artinya model pembelajaran Project Based Learning efektif terhadap hasil belajar IPA kelas V SD Negeri 1 Pasar Banggi Rembang.

Berdasarkan hasil penelitian ini, maka saran yang dapat diajukan adalah sebagai berikut 1) Model Project Based Learning diharapkan dapat menjadi alternatif model pembelajaran yang bisa diterapkan di kelas sesuai dengan materi pembelajaran maupun karakter siswa. 2) Pelaksanaan pembelajaran dengan menerapkan model Project Based Learning perlu bimbingan guru baik dalam perancangan desain proyek maupun dalam pembuatan proyek untuk memperoleh hasil yang maksimal.

\section{DAFTAR PUSTAKA}

Aliefyan, Retha Rose. 2014. Kefektifan Stategi Project Based Learning Berbantu Modul Pada Hasil Belajar Kimia Siswa.Jurnal Inovasi Pendidikan Kimia, 8(2): 1360-1369.

Amanda, N. W. Y. 2014. Pengaruh Model Pembelajaran Berbasis Proyek Terhadap Hasil Belajar IPA Ditinjau Dari Self Efficacy Siswa. E-Journal Program Pascasarjana Universitas Pendidikan Ganesha, 4: 1-11.

Amirono dan Daryanto. 2016. Evaluasi \& Penilaian Pembelajaran Kurikulum 2013. Yogyakarta: Gava Media.

Andana, Edi. 2014. Pengaruh Model Pembelajaran Berbasis Proyek Terhadap Hasil Belajar IPA Siswa Kelas IV SD Di Gugus V Kecamatan Tegallalang.Jurnal Mimbar PGSD Universitas Pendidikan Ganesha, 2(1): $1-9$.

Andari, Ni Made Nepri. 2016. Penerapan Model Project Based Learning Berorientasi Pendidikan Karakter Untuk Meningkatkan Hasil Belajar IPA Siswa Kelas IV SDN 20 Dangin Puri.E-Journal PGSD Universitas Pendidikan Ganesha, 4(1): 1-12.

Anitah, Sri. 2012. Strategi Pembelajaran di SD. Tangerang Selatan: Universitas Terbuka.

Arikunto, Suharsimi. 2014. Prosedur Penelitian Suatu Pendekatan Praktik. Jakarta: Rineka Cipta.

Dewi, Santi. 2017. Efektivitas Model Project Based Learning Terhadap Ketuntasan Hasil Belajar Siswa Pada Materi Konsep Energi Gerak Di Kelas III SDN 2 Banda Aceh.Jurnal Pendidikan Dasar Universitas Negeri Medan.

Dimyati dan Mudjiono. 2013. Belajar \& Pembelajaran. Jakarta: Rineka Cipta.

Fathurrohman, Muhammad. 2017. Model-Model Pembelajaran Inovatif. Jogjakarta: Ar-Ruzz Media.

Jagantara, Wirasana. 2014. Pengaruh Model Pembelajaran Berbasis Proyek (Project Based Learning) Terhadap hasil belajar Biologi Ditinjau Dari Gaya Belajar Siswa SMA.e-Journal Program Pascasarjana Universitas Pendidikan Ganesha, 4: 1-11.

Kadir, Abd dan Hanun Asrohah. 2014. Pembelajaran Tematik. Jakarta: PT RajaGrafindo Persada. 
Kamayani, Diah. Pengaruh Model Pembelajaran Project Based Learning Berbantuan Media Tiga Dimensi Terhadap Hasil Belajar IPA Di SD Gugus IX Kecamatan Buleleng.Jurnal Universitas Pendidikan Ganesha.

Khoiri, Nur. 2016. Efektifitas Model Project Based Learning terhadap Keterampilan Proses Sains dan Kemampuan Berpikir Kreatif Siswa pada Pokok Bahasan Kalor Kelas X SMAN 1 Wonosegoro Tahun Pelajaran 2014/2015.Jurnal Penelitian Pembelajaran Fisika, 7(1): 19-24.

Khoiri, Nur. 2016. Keefektifan Model Pembelajaran PjBL (Project Based Learning) terhadap Kemampuan Kreativitas dan Hasil Belajar Siswa Kelas XI. Jurnal Penelitian Pembelajaran Fisika, 7(2): 142-146.

Kusuma, Santi Fajarwati. 2017. Pengaruh Project Based Learning Berbantu Multimedia Terhadap Keterampilan Memecahkan Masalah Dan Hasil Belajar Psikomotor Siswa Kelas XI SMA.Jurnal Pendidikan, 2(3): 315-321.

Munir. 2012. Multimedia Konsep \& Aplikasi dalam Pendidikan. Bandung: Alfabeta.

Masykur, Rubhan. 2017. Pengembangan Media Pembelajaran Matematika dengan Macromedia Flash.Jurnal Pendidikan Matematika, 8(2): 177-186.

Nursit, Isbadar. Pengembangan Multimedia Interaktif Berbasis Power Point (Macro-Enabled) Pada Mata Kuliah Geometri Euclid Dalam Pembalajaran Matematika. Jurnal Media Pendidikan Matematika

Nyoman, Ni Parwati. 2018. Belajar dan Pembelajaran. Depok: PT RajaGrafindo Persada.

Peraturan Pemerintah No. 32 Tahun 2013 tentang Standar Nasional Pendidikan. 2013.

Peraturan Menteri Pendidikan dan Kebudayaan No. 22. Tentang Standar Proses. 2016.

PISA 2015. PISA 2015 Result in Fokus: OECD Better Policies For Better Lives.

Purwandari, Novita. 2015. Peningkatan Keterampilan Proses Dan Hasil Belajar IPA Melalui Penerapan Model Pembelajaran Berbasis Proyek Pada Siswa Kelas IV SD Negeri 2 Srandakan.Jurnal PGSD UNY.

Saputra, dkk. 2018. SUPLEMEN Pengembangan Pendidikan IPA SD. Semarang: Jurusan PGSD FIP Universitas PGRI Semarang.

Saputra, dkk. 2015. Dasar-dasar Pendidikan IPA SD. Semarang: Jurusan PGSD FIP Universitas PGRI Semarang.

Sudjana. 2005.Metoda Statistika. Bandung: Tarsito.

Sugiyono. 2018. Metode Penelitian kuantitatif, kualitatif dan R\&D. Bandung: Alfabeta.

Sulaeman, Maman. Aplikasi Project Based Learning (PBL) Untuk Membangun Keterampilan Berpikir Kritis dan Kreatif Siswa. Depok: Bioma Publishing.

Suyono dan Hariyanto. 2011. Belajar dan Pembelajaran Teori dan Konsep Dasar. Bandung: PT Remaja Rosdakarya.

Undang-Undang Republik Indonesia Nomor 20 Tahun 2003 tentang Sistem Pendidikan Nasional

Widi, Asih Wisudawati. 2017. Metodologi Pembelajaran IPA. Jakarta: Bumi Aksara.

Wilis, Ratna Dahan. 2011. Teori-teori Belajar dan Pembelajaran. Jakarta: Erlangga. 